\title{
A STUDY ON INCOME DISTRIBUTION AND SOCIO-ECONOMIC CON- DITIONS OF MGNREGA HOUSEHOLDS
}

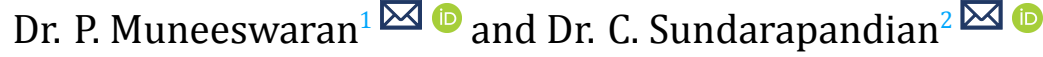 \\ ${ }^{1}$ Teaching Assistant, P.G. \& Research Department of Economics, A.P.A. College of Arts \& Culture, Palani, Dindigul District, \\ 624 601, Tamil Nadu, India. Tel.: 9500683894 \\ ${ }^{2}$ Assistant Professor of Economics, P.G. \& Research Department of Economics, A.P.A. College of Arts \& Culture, Palani, \\ Dindigul District, 624 601, Tamil Nadu, India. Tel.: 8248598331
}
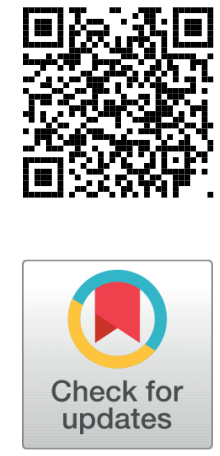

Received 1 June 2021

Accepted 15 June 2021

Published 30 June 2021

Corresponding Author

Dr. P. Muneeswaran, Muneeswara

n.P.One@Gmail.Com

DOI $10.29121 /$

granthaalayah.v9.i6.2021.4044

Funding: This research received no specific grant from any funding agency in the public, commercial, or not-for-profit sectors.

Copyright: (C) 2021 The Author(s). This is an open access article distributed under the terms of the Creative Commons Attribution License, which permits unrestricted use, distribution, and reproduction in any medium, provided the original author and source are credited.

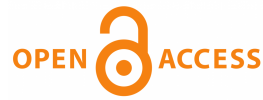

\section{ABSTRACT}

The Mahatma Gandhi National Rural Employment Guarantee Act (MGNREGA) 2005 is one of the foremost social security programmes in India. It guarantees minimum wage, reduces poverty and checks large scale migration in rural India. It has reduced rural hunger. After implementation of MGNREGA, the Planning Commission estimated that the poverty among Scheduled Castes (SCs) in rural areas fell 22 percentage points- from 53.5 per cent in 2004-05 to 31.5 per cent in 2011-12. For that reason, the study focuses on income distribution and the socio-economic conditions of MGNREGA workers and their households in Dindigul district of Tamil Nadu state. The sample size of this research work is 345 MGNREGA Scheduled Castes (SCs) workers. The study found that there is a significant level of association existing between the annual income of MGNREGA workers/households and their socio-economic conditions, such as the participants' gender, age, community and occupation, type of family, size of family, number of employees and migrant workers of the family in the study area. At the same time this study found that there is no significant level association existing between annual income and socio-economic conditions such as education, type of houses, and marital status. Hence, the MGNREGA is one of the major factors in determining the income level and also the socio-economic conditions of the of scheduled castes workers in the study area.

Keywords: Mgnrega, Income Analysis, SocioEconomic Conditions, Scheduled Castes, Migration

\section{INTRODUCTION}

The Mahatma Gandhi National Rural Employment Guarantee Act (MGNREGA) is one of the foremost social security programmes in India. It guarantees minimum wage, reduction of poverty, and checks migration of population from rural areas to urban 
areas and reducing rural hunger. The National Rural Employment Guarantee Act (NREGA) was an Indian job guarantee scheme, enacted by the legislature of India on $25^{\text {th }}$ August, 2005 and it had come into force and implemented on $2^{\text {nd }}$ February, 2006 in the Anantapur district, Andhra Pradesh. The act was renamed as Mahatma Gandhi National Rural Employment Guarantee Act (MGNREGA) on $2^{\text {nd }}$ October 2009. It was implemented in all the states of India in three different phases. Phase-I was introduced in 200 of the most backward districts of the country out of the total districts of 615, and again with an additional to 130 districts in phase-II $2007-2008$. The Act was notified in the remaining 285 rural districts of India from April 1, 2008 in phase-III "Ministry Of Law And Justice Of India " (2005).

The Act guarantees to one who works minimum hundred days out of 365 days per year and he/she must give some requisition within fifteen days. An unemployment allowance should be provided to the inability workers, one who is not able to work for 15 days from the date, the Act provided some compensation Mukherjee (2016).

Initially, it ensured that the legal right to work for a hundred days for poor people, who was willing to work for a minimum wage rate, especially in rural areas, that would turn to reduce the flow of rural to urban migration. Its addition to, other important objective of the Act is to strengthened the Panchayat Raj Institution (PRIs)

The major dimensions of the impact of MGNREGA could be summarized by the following activities such as, increased employment opportunities, major participation by poor SC and ST population, economic empowerment of poor women, relief from rural village from moneylenders, disengagement from hazardous work, rural asset formation, improvement in rural environment and sanitation, creates SHG by MGNREGA, reducing the rural partiality, hunger, unemployment and migration.

The Act creates some awareness to the people about the Panchayat Raj Institution and government activities, increasing purchasing power and agricultural production, savings, increase in income, expenditure and strengthening the PRI.

The average days of work allocated to the ST job-card householders were less than for the SC communities, but the former group had less easy access to the registration of job cards and spent more time getting the jobs than other social groups. Only 36 per cent of the tribal respondents were aware of the provision for a minimum number of days of employment, a lower percentage than from the SC and general communities. Similarly, only 42 percent of tribal respondents were aware of the provision for a minimum wage rate in the scheme; this was a larger percentage than their SC counterparts but lagged far behind those from the $\mathrm{OBC}$ and general communities Mishra et al. (2010). In addition, an interesting and encouraging observation was the scheme to reduce the migration of people from rural to urban areas Devi et al. (2011). The Act has a positive contribution to the generation of employment, social protection for women and eradicating the poverty in rural areas Mary and M (2014). 


\section{STATEMENT OF THE PROBLEM}

The MGNREGA is the main reason to economic changes in rural areas. The wage rates have increased in agriculture and allied activities in rural regions. It creates a shortage of labourers in agriculture and allied activities. There is no wage rate difference existing between the wages of MGNREGA and females' wage of agriculture at present. Hence women's participation is very high, especially SC women. The Act ensures a minimum wage to the workers. The minimum wage will not create high productivity and changes in rural areas. Many poverties alleviation programmes have not achieved the target because of, lack of management, expensive administration, corruption, political intervention and so on. The MGNREGA Act also has the same problems. The Act has not considered the classifications of various factors such as economic, occupation, geographical location, socio-culture and rural divisions.

In this study area, researcher identified many problems while collecting data from the workers such as no work side facilities, wage determination problem, degradation of grazing land, create laziness among rural youths, low work productivity (may be "Not worked"), lack of work tools, lack of awareness and administration problems, political intervention, partiality, corruption, and the participants are the pregnant women, children and old aged person.

\section{OBJECTIVE}

The basic objective of the study is to analyze the income distribution and social economic conditions of MGNREGA Households in Dindigul district of Tamil Nadu.

\section{SIGNIFICANCE OF THE STUDY}

In India, Scheduled Castes (SCs) people are mainly depending upon the agriculture and agricultural related activities. There are no alternative employment opportunities available for most of the SCs population other than agriculture operations. The Planning Commission in the year 2004-05 had estimated that more than half the SCs (about 53.5 percent) in rural areas were living below the poverty line. After implementation of MGNREGA, the poverty among SCs in rural areas fell 22 percentage points- from 53.5 per cent in 2004-05 to 31.5 per cent in 2011-12 Jha (2014).

In this situation the Act was introduced (Phase-I) in 200 most backward districts of the country for poor Below Poverty Line - (BPL) people. As a result, 62 per cent of the new employment by MGNREGA in Phase I and II are utilized by the SC and ST communities, since majority of them are very poor as high. Only six districts were covering in Phase I implementation in Tamil Nadu State such as the districts are Cuddalore, Dindigul, Nagapattinam, Sivagangai, Tiruvannamalai, Viluppuram. The Dindigul district was selected on the basis of most economic backward district index of Tamil Nadu. 
The Act was implemented without any consideration of rural -regional differences. Therefore, the study was done purposefully and selected different rural regions, such as city surrounded rural regions, primitive rural region/hilly regions and backward rural regions.

\section{LIMITATIONS OF THE STUDY}

The study has covered micro region of Dindigul district only. The researcher interacted only with Scheduled Castes people, not with the people of other communities. Troubles also were faced in getting relevant data from the villages.

\section{METHODS AND MATERIALS}

The study has been carried out in the area of Dindigul district of Tamil Nadu state during the period of 2012-2016. The field survey has been carried out from May 2014 to June 2015. Out of 14 blocks of Dindigul district, only three blocks were selected purposefully, such as city surrounded rural regions of Dindigul block, primitive rural region/hilly regions of Kodaikanal block and backward rural regions of Batlagundu block. The sample size of the study is 345. They were selected from MGNREGA workers of Scheduled castes communities through proportionate random sampling technique at 10 per cent level, which constituted 130 (37.70 per cent), 90 (26.10 per cent) and 125 (36.20 per cent) samples from Dindigul block, Kodaikanal block and Batlagundu block respectively. Three village Panchayats were selected from each block. The major beneficiaries were scheduled castes people in the nine village Panchayats.

\section{ANALYSIS THE INCOME DISTRIBUTION AND SOCIO-ECONOMIC CONDITIONS (RESPONDENTS/HOUSEHOLDS)}

The annual income of MGNREGA workers and their family represents with the variables of gender, age, education, marital status, community, occupation, types of houses, types of family, size of family, and the number of employees/income earners and migrant workers of the family. Karl Pearson Chi-square test was used in the income distribution analysis on socio-economic conditions.

\section{Pearson Chi-Square Test}

Chi-Square, symbolically written as $\mathrm{x}^{2}$ (Pronounced as Ki-square), is a statistical measure used in the context of sampling analysis for comparing a variance to a theoretical variance Kothari (2004). As a non-parametric test, it "could be used to determine if categorical data show dependency or the two classifications are independent. It could also be used to make comparisons between theoretical populations and actual data when categories are used". Neil and R (1978)

$$
X^{2}=\sum \frac{\left(O_{i j}-E_{i j}\right)^{2}}{E_{i j}}
$$


$\mathrm{O}_{i j}$ - Observed frequency of the cell in ith row and jth column.

$\mathrm{E}_{i j}$ - Expected frequency of the cell in ith row and jth column.

$E=\frac{R T \times C T}{N}$

E - Expected frequency.

RT - The row total is row containing the cell.

CT - The column total is column containing the cell.

$\mathrm{N}$ - The total number of observations.

The table value is calculated from $V=(r-1)(c-1)$. Where, $r$ is row and $c$ are column.

\subsection{ANALYSIS THE INCOME DISTRIBUTION AND SOCIO-ECONOMIC CONDITIONS (RESPONDENTS)}

\subsubsection{ASSOCIATION BETWEEN INCOME AND GENDER}

Gender is an important factor in family and society. The Act is providing equal wages to their workers without any discrimination. Under the Act of wage payments, gender disparity is totally removed Veena (2015).

\begin{tabular}{|c|c|c|c|c|c|c|}
\hline \multirow[t]{3}{*}{ Sl. No } & \multirow[t]{3}{*}{ Annual Income in Rs. } & \multicolumn{4}{|c|}{ GENDER } & \multirow[t]{2}{*}{ Total (\%) } \\
\hline & & \multicolumn{2}{|c|}{ Male } & \multicolumn{2}{|c|}{ Female } & \\
\hline & & $0(\%)$ & E & $\mathrm{O}(\%)$ & E & \\
\hline 1 & Up to 24000 & $16(14.8)$ & 29.11 & $77(32.5)$ & 63.89 & $93(27.0)$ \\
\hline 2 & $24001-36000$ & $21(19.4)$ & 23.17 & $53(22.4)$ & 50.83 & $74(21.4)$ \\
\hline 3 & $36001-48000$ & 45 (41.7) & 34.43 & $65(27.4)$ & 75.57 & $110(31.9)$ \\
\hline 4 & Above 48000 & $26(24.1)$ & 21.29 & 42 (17.7) & 46.71 & 68 (19.7) \\
\hline & Aggregate (\%) & \multicolumn{2}{|c|}{$108(31.3)$} & \multicolumn{2}{|c|}{237 (68.7) } & $345(100)$ \\
\hline
\end{tabular}

Source: Computed from Primary Data O-Observed Frequency E-Expected Frequency Note: $\mathrm{O}$ and $\mathrm{E}$ values are mentioned for Chi-square test Calculation

The Table 1 revealed that, about 65.8 per cent of Males earnings were above Rs. 36000 than females' earnings of below Rs.36000 (about 54.9 per cent) annually from various works, not only the programme. Male were dominated in getting annual income than female, in spite of female are widely rolling in rural making of India such as backbone of agricultural activities, home making, construction and micro-small enterprises of rural. Wage discrimination is no more in MGNREGA. Female participants (about 68.7 percent) were higher than Male in the study area.

\subsubsection{ASSOCIATION BETWEEN INCOME AND AGE}

The age limit for the participants of MGNREGA workers is 18 years and above for female, and 21 years for Male. As a rule, age of below 21 years of respondents is not appearing. The youngest age group of respondents' is contributing to the risk bearing of MGNREGA works and they are called as skilled labourers. 


\begin{tabular}{|c|c|c|c|c|c|c|c|c|c|c|}
\hline \multirow{3}{*}{$\begin{array}{l}\text { Sl. } \\
\text { No }\end{array}$} & \multirow{3}{*}{$\begin{array}{c}\text { Annual } \\
\text { Income in Rs. }\end{array}$} & \multicolumn{8}{|c|}{ AGE (In Years) } & \multirow{3}{*}{$\begin{array}{l}\text { Total } \\
(\%)\end{array}$} \\
\hline & & \multicolumn{2}{|c|}{ Below 30} & \multicolumn{2}{|c|}{$31-40$} & \multicolumn{2}{|c|}{$41-50$} & \multicolumn{2}{|c|}{ Above 50} & \\
\hline & & $\begin{array}{c}0 \\
(\%)\end{array}$ & $\mathbf{E}$ & $\begin{array}{c}0 \\
(\%)\end{array}$ & $\mathbf{E}$ & $\begin{array}{c}0 \\
(\%)\end{array}$ & $\mathbf{E}$ & $\begin{array}{c}0 \\
(\%)\end{array}$ & $\mathbf{E}$ & \\
\hline 1 & Up to 24000 & $\begin{array}{c}34 \\
(40.0)\end{array}$ & 22.91 & $\begin{array}{c}21 \\
(21.4)\end{array}$ & 26.42 & $\begin{array}{c}17 \\
(23.9)\end{array}$ & 19.14 & $\begin{array}{c}21 \\
(23.1)\end{array}$ & 24.53 & $\begin{array}{c}93 \\
(27.0)\end{array}$ \\
\hline 2 & $24001-36000$ & $\begin{array}{c}20 \\
(23.5)\end{array}$ & 18.23 & $\begin{array}{c}13 \\
(13.3)\end{array}$ & 21.02 & $\begin{array}{c}18 \\
(25.4)\end{array}$ & 15.23 & $\begin{array}{c}23 \\
(25.3)\end{array}$ & 19.52 & $\begin{array}{c}74 \\
(21.4)\end{array}$ \\
\hline 3 & $36001-48000$ & $\begin{array}{c}14 \\
(16.5)\end{array}$ & 27.10 & $\begin{array}{c}42 \\
(42.9)\end{array}$ & 31.25 & $\begin{array}{c}24 \\
(33.8)\end{array}$ & 22.64 & $\begin{array}{c}30 \\
(32.9)\end{array}$ & 29.01 & $\begin{array}{c}110 \\
(31.9)\end{array}$ \\
\hline 4 & Above 48000 & $\begin{array}{c}17 \\
(20.0)\end{array}$ & 16.75 & $\begin{array}{c}22 \\
(22.5)\end{array}$ & 19.32 & $\begin{array}{c}12 \\
(16.9)\end{array}$ & 13.99 & $\begin{array}{c}17 \\
(18.7)\end{array}$ & 17.94 & $\begin{array}{c}68 \\
(19.7)\end{array}$ \\
\hline & gregate (\%) & $85(2$ & 6) & $98(2$ & .4) & $71(2$ & .6) & $91(2$ & .4) & $\begin{array}{c}345 \\
(100)\end{array}$ \\
\hline
\end{tabular}

Source: Computed from Primary Data

The Table 2 , revealed that the age group of 31-40 years was a majority in annual earnings (Rs. 36001-48000, 42.9 per cent) than other majority earner's age groups of below 31 (Rs. Below 24001, 40.0 per cent), 41-50 (Rs. 36001-48000, 33.8 per cent) and above 50 (Rs. 36001-48000, 32.9 per cent) respectively. They have earned income from MGNREGA and other employment sources. The majority of the participants were belonged the age group of 31-40 that is 28.4 per cent of the respondents.

\subsubsection{ASSOCIATION BETWEEN INCOME AND EDUCATIONAL STATUS}

In general, literate people have more information about the MGNREGA than illiterate people. This awareness includes the details on the basis of work status, working hours, financial and physical status of the MGNREGA.

\begin{tabular}{|c|c|c|c|c|c|c|}
\hline \multirow{3}{*}{ Sl. No } & \multirow[t]{3}{*}{ Annual Income in Rs. } & \multicolumn{4}{|c|}{ EDUCATION } & \multirow[t]{3}{*}{ Total (\%) } \\
\hline & & \multicolumn{2}{|c|}{ Illiterate } & \multicolumn{2}{|c|}{ Literate } & \\
\hline & & $0(\%)$ & $\mathbf{E}$ & $\mathrm{O}(\%)$ & $\mathbf{E}$ & \\
\hline 1 & Up to 24000 & $48(27.0)$ & 47.98 & 45 (26.9) & 45.02 & $93(27.0)$ \\
\hline 2 & $24001-36000$ & $34(19.1)$ & 38.18 & $40(24.0)$ & 35.82 & $74(21.4)$ \\
\hline 3 & $36001-48000$ & $56(31.5)$ & 56.75 & $54(32.3)$ & 53.25 & $110(31.9)$ \\
\hline 4 & Above 48000 & $40(22.4)$ & 35.08 & $28(16.8)$ & 32.92 & 68 (19.7) \\
\hline & Aggregate (\%) & \multicolumn{2}{|c|}{$178(51.6)$} & \multicolumn{2}{|c|}{$167(48.4)$} & 345 (100) \\
\hline
\end{tabular}

Source: Computed from Primary Data

The Table 3 revealed that, the literate (31.5 per cent) and illiterate (32.53per cent) peoples were leading annual income group of Rs. 36001-48000. The difference between literate and illiterate participants were existed only 3.2 per cent in MGN- 
REGA.

\subsubsection{ASSOCIATION BETWEEN INCOME AND MARITAL STATUS}

The study doesn't job cardholders based. It is Easy to determine that cardholders are married. Normally MGNREGA participants are not fully job card. The card may be wife or husband or father or mother. Cardholders are participants, but not necessary as participants are cardholders.

Table 4 Association between Income and Marital Status

\begin{tabular}{|c|c|c|c|c|c|c|c|c|}
\hline \multirow{3}{*}{$\begin{array}{l}\text { Sl. } \\
\text { No }\end{array}$} & \multirow{3}{*}{$\begin{array}{l}\text { Annual Income in } \\
\text { Rs. }\end{array}$} & \multicolumn{6}{|c|}{ MARITAL STATUS } & \multirow{2}{*}{$\begin{array}{l}\text { Total } \\
(\%)\end{array}$} \\
\hline & & \multicolumn{2}{|c|}{ Married } & \multicolumn{2}{|c|}{ Unmarried } & \multicolumn{2}{|c|}{ Others } & \\
\hline & & $0(\%)$ & $\mathbf{E}$ & $0(\%)$ & $\mathbf{E}$ & $0(\%)$ & $\mathbf{E}$ & \\
\hline 1 & Up to 24000 & $76(26.9)$ & 76.29 & $\begin{array}{c}5 \\
(31.3)\end{array}$ & 4.31 & $\begin{array}{c}12 \\
(26.1)\end{array}$ & 12.40 & $93(27.0)$ \\
\hline 2 & $24001-36000$ & $58(20.5)$ & 60.70 & $\begin{array}{c}5 \\
(31.3)\end{array}$ & 3.43 & $\begin{array}{c}11 \\
(23.9)\end{array}$ & 9.87 & 74 (21.4) \\
\hline 3 & Above 36000 & $\begin{array}{c}149 \\
(52.6)\end{array}$ & 146.01 & $\begin{array}{c}6 \\
(37.4)\end{array}$ & 8.26 & $\begin{array}{c}23 \\
(50.0)\end{array}$ & 23.73 & $\begin{array}{c}178 \\
(51.6)\end{array}$ \\
\hline & Aggregate (\%) & $283(8$ & $2.0)$ & 16( & & $46(1$ & & $\begin{array}{c}345 \\
(100)\end{array}$ \\
\hline
\end{tabular}

Source: Computed from Primary Data

The Table 4 revealed that, the married, others (widow or widower) and unmarried participants are getting high annual income of above Rs. 36000 (52.6 per cent, 50.0 per cent and 37.4 per cent) respectively. Married participants got more income than other two marital statuses of unmarried and others. Married participants were majority in MGNREGA (82.0 per cent).

\subsubsection{ASSOCIATION BETWEEN INCOME AND COMMUNITY}

The Scheduled Caste Arunthathiyar (SCA) means that the castes, like Arunthathiyar, Chakkiliyan, Madari, Madiga, Pagadai, Thoti and Adi Andhra within the list of 76 Scheduled Castes [Remain 69 Castes are -Scheduled Castes General (SCG), majorities are Adi Diravidars, Pallars or Deventhira Kulathars and Paraiyars] notified by the President of India under the Article 341 of the Constitution of India. "Adi Dravidar And Tribal Welfare Department Of Tamil Nadu" (2009)

The Table 5 revealed that leading annual income groups were Rs. 36001-48000 (35.0 per cent) of SCG and Above Rs. 48000 (28.7 per cent) of SCA respectively. SCG has more income than SCA from local employment opportunities. SCG participants were higher than SCA in the study area (64.6 per cent). 


\begin{tabular}{|c|c|c|c|c|c|c|}
\hline \multirow[t]{3}{*}{ Sl. No } & \multirow{3}{*}{ Annual Income in Rs. } & \multicolumn{4}{|c|}{ COMMUNITY } & \multirow[t]{3}{*}{ Total (\%) } \\
\hline & & \multicolumn{2}{|c|}{ SCG } & \multicolumn{2}{|c|}{ SCA } & \\
\hline & & $0(\%)$ & $\mathbf{E}$ & $0(\%)$ & $\mathbf{E}$ & \\
\hline 1 & Up to 24000 & $62(27.8)$ & 60.11 & 31 (25.4) & 32.89 & $93(27.0)$ \\
\hline 2 & $24001-36000$ & $50(22.4)$ & 47.83 & 24 (19.7) & 26.17 & 74 (21.4) \\
\hline 3 & $36001-48000$ & $78(35.0)$ & 71.10 & $32(26.2)$ & 38.90 & $110(31.9)$ \\
\hline 4 & Above 48000 & 33 (14.8) & 43.95 & 35 (28.7) & 24.05 & 68 (19.7) \\
\hline & Aggregate (\%) & \multicolumn{2}{|c|}{$223(64.6)$} & \multicolumn{2}{|c|}{$122(35.4)$} & $345(100)$ \\
\hline
\end{tabular}

Source: Computed from Primary Data

\subsubsection{ASSOCIATION BETWEEN INCOME AND OCCUPATIONS}

Before two decades back most of the people were in agriculture sector and allied actives in rural India. Nowadays rural-urban connectivity, infrastructure facilities, technologies have improved the rural society with modern India. They are not depending on agriculture alone. In this situation the study analyses their income distribution from various occupations of the rural.

Table 6 Association between Income and Occupations

\begin{tabular}{|c|c|c|c|c|c|c|c|c|c|c|}
\hline \multirow{3}{*}{$\begin{array}{l}\text { Sl. } \\
\text { No }\end{array}$} & \multirow{3}{*}{$\begin{array}{c}\text { Income } \\
\text { in Rs. }\end{array}$} & \multicolumn{8}{|c|}{ OCCUPATIONS } & \multirow{3}{*}{$\begin{array}{l}\text { Total } \\
(\%)\end{array}$} \\
\hline & & \multicolumn{2}{|c|}{ Farmer } & \multicolumn{2}{|c|}{$\begin{array}{l}\text { Cooli- } \\
\text { Agriculture }\end{array}$} & \multicolumn{2}{|c|}{$\begin{array}{l}\text { Cooli- Non- } \\
\text { Agriculture }\end{array}$} & \multicolumn{2}{|c|}{$\begin{array}{c}\text { Self- } \\
\text { employers / } \\
\text { Housewife }\end{array}$} & \\
\hline & & $0(\%)$ & $\mathbf{E}$ & O (\%) & $\mathbf{E}$ & $0(\%)$ & $\mathbf{E}$ & $0(\%)$ & $\mathbf{E}$ & \\
\hline 1 & $\begin{array}{l}\text { Up to } \\
36000\end{array}$ & $\begin{array}{c}31 \\
(37.7)\end{array}$ & 39.69 & $\begin{array}{c}42 \\
(36.5)\end{array}$ & 55.67 & $\begin{array}{c}22 \\
(37.3)\end{array}$ & 28.56 & $\begin{array}{c}72 \\
(80.9)\end{array}$ & 43.08 & $\begin{array}{l}167 \\
(48.4)\end{array}$ \\
\hline 2 & $\begin{array}{c}36001- \\
48000\end{array}$ & $\begin{array}{c}32 \\
(39.0)\end{array}$ & 26.14 & $\begin{array}{c}47 \\
(40.9)\end{array}$ & 36.67 & $\begin{array}{c}24 \\
(40.7)\end{array}$ & 18.81 & $7(7.8)$ & 28.38 & $\begin{array}{l}110 \\
(31.9)\end{array}$ \\
\hline 4 & $\begin{array}{l}\text { Above } \\
48000\end{array}$ & $\begin{array}{c}19 \\
(23.1)\end{array}$ & 16.16 & $\begin{array}{c}26 \\
(22.6)\end{array}$ & 22.67 & $\begin{array}{c}13 \\
(22.0)\end{array}$ & 11.63 & $\begin{array}{c}10 \\
(11.2)\end{array}$ & 17.54 & $\begin{array}{l}68 \\
(19.7)\end{array}$ \\
\hline & gate $(\%)$ & $82(2$ & & 115( & 3.3) & 59 & & $89(2$ & $8)$ & $\begin{array}{l}345 \\
(100)\end{array}$ \\
\hline
\end{tabular}

Source: Computed from Primary Data

The Table 6 revealed that agricultural labourers, non-agriculture laboures and Farmers were dominant in the income group of Rs. 36001-48000/-, 40.9 per cent, 40.7 per cent and 39.0 per cent respectively. While, Self-employers/Housewives were dominant income group of below Rs. 36001(80.9 per cent) than other occupational groups. Daily agricultural laborers (Agri-cooli) were the major participants in the study area (33.3 per cent). 


\subsection{ANALYSIS THE INCOME DISTRIBUTION AND SOCIO-ECONOMIC CONDITIONS (HOUSEHOLDS)}

\subsubsection{ASSOCIATION BETWEEN ANNUAL INCOME AND TYPE OF HOUSE}

Before introduction of the MGNREGA too many of Thatched and Tiled houses were in rural India than concrete houses. At present, more concrete houses are there than Thatched and tiled houses due to bank loan, Central and State governments housing schemes, NGO and Tamil Nadu Adi Dravidar Housing and Development Corporation (TAHDCO). Hence their housing types were classified with their household income.

Table 7 Association between annual income and type of houses

\begin{tabular}{|c|c|c|c|c|c|c|c|c|}
\hline \multirow{3}{*}{$\begin{array}{l}\text { Sl. } \\
\text { No }\end{array}$} & \multirow{3}{*}{$\begin{array}{c}\text { Income In } \\
\text { Rs. }\end{array}$} & \multicolumn{6}{|c|}{ TYPES OF HOUSES } & \multirow[t]{3}{*}{ Total (\%) } \\
\hline & & \multicolumn{2}{|c|}{ Thatched/Tiled } & \multicolumn{2}{|c|}{ Concrete } & \multicolumn{2}{|c|}{ Others } & \\
\hline & & $0(\%)$ & $\mathbf{E}$ & $0(\%)$ & $\mathbf{E}$ & $\mathrm{O}(\%)$ & $\mathbf{E}$ & \\
\hline 1 & Up to 36000 & $\begin{array}{c}34 \\
(19.9)\end{array}$ & 29.74 & $\begin{array}{c}21 \\
(15.6)\end{array}$ & 19.65 & $5(8.2)$ & 10.61 & $60(17.4)$ \\
\hline 2 & $36001-48000$ & $\begin{array}{c}29 \\
(17.0)\end{array}$ & 34.20 & $\begin{array}{c}28 \\
(24.8)\end{array}$ & 22.60 & $\begin{array}{c}12 \\
(19.7)\end{array}$ & 12.20 & $69(20.0)$ \\
\hline 3 & $48001-60000$ & $\begin{array}{c}48 \\
(28.1)\end{array}$ & 44.11 & $\begin{array}{c}24 \\
(21.2)\end{array}$ & 29.15 & $\begin{array}{c}17 \\
(27.9)\end{array}$ & 15.74 & $89(25.8)$ \\
\hline 4 & Above 60000 & $\begin{array}{c}60 \\
(35.0)\end{array}$ & 62.95 & $\begin{array}{c}40 \\
(35.4)\end{array}$ & 41.60 & $\begin{array}{c}27 \\
(44.2)\end{array}$ & 22.46 & $\begin{array}{c}127 \\
(36.8)\end{array}$ \\
\hline \multicolumn{2}{|c|}{ Aggregate (\%) } & \multicolumn{2}{|c|}{$171(49.5)$} & \multicolumn{2}{|c|}{$113(32.8)$} & \multicolumn{2}{|c|}{$61(17.7)$} & $345(100)$ \\
\hline
\end{tabular}

Source: Computed from Primary Data

The Table 7 reveals that, annual earns were above Rs. 60000 from each type of housing of respondents' households, such as Thatched or Tiled (35.0 per cent), Concrete (35.4 per cent) and other (mixed) type house (44.2 per cent). Mixing or other type houses (44.2 per cent) of households were majority in above that income group than the Thatched or Tiled and Concrete households. Thatched/Tiled houses of the respondents were major participants in MGNREGA (49.5 per cent).

\subsubsection{ASSOCIATION BETWEEN ANNUAL INCOME AND TYPES OF FAMILY}

Family is an important social institution. Types of family are classified into two categories, nuclear family and joint family.

The Table 8 indicates that, joint families were leading in getting annual income than nuclear families. Both type of families was belonged the leading income group of above Rs.60000 (59.4 per cent) and below Rs. 48000 (40.9 per cent) respectively. Nuclear families (82.9 per cent) participation was higher than joint families (17.1) in the study area. 


\begin{tabular}{|c|c|c|c|c|c|c|}
\hline \multirow[t]{3}{*}{ Sl. No } & \multirow[t]{3}{*}{ Income In Rs. } & \multicolumn{4}{|c|}{ TYPE OF FAMILY } & \multirow[t]{2}{*}{ Total (\%) } \\
\hline & & \multicolumn{2}{|c|}{ Nuclear } & \multicolumn{2}{|c|}{ Joint } & \\
\hline & & $0(\%)$ & $\mathbf{E}$ & $0(\%)$ & $\mathbf{E}$ & \\
\hline 1 & Up to 48000 & $117(40.9)$ & 106.94 & $12(20.3)$ & 22.06 & $129(37.4)$ \\
\hline 2 & $48001-60000$ & 77 (26.9) & 73.78 & $12(20.3)$ & 15.22 & $89(25.8)$ \\
\hline 3 & Above 60000 & $92(32.2)$ & 105.28 & $35(59.4)$ & 21.72 & $127(36.8)$ \\
\hline \multicolumn{2}{|c|}{ Aggregate (\%) } & \multicolumn{2}{|c|}{$286(82.9)$} & \multicolumn{2}{|c|}{$59(17.1)$} & $345(100)$ \\
\hline
\end{tabular}

Source: Computed from Primary Data

\subsubsection{ASSOCIATION BETWEEN ANNUAL INCOME AND SIZE OF FAMILY}

Annual household income and size of family described the statement of 'more members of the family as more income'.

\begin{tabular}{|c|c|c|c|c|c|c|c|c|}
\hline \multirow{3}{*}{$\begin{array}{l}\text { Sl. } \\
\text { No }\end{array}$} & \multirow{3}{*}{$\begin{array}{c}\text { Income In } \\
\text { Rs. }\end{array}$} & \multicolumn{6}{|c|}{ SIZE OF FAMILY (In Count) } & \multirow{2}{*}{$\begin{array}{l}\text { Total } \\
(\%)\end{array}$} \\
\hline & & \multicolumn{2}{|c|}{$1-2$} & \multicolumn{2}{|c|}{$3-4$} & \multicolumn{2}{|c|}{ Above 4} & \\
\hline & & $0(\%)$ & $\mathbf{E}$ & $0(\%)$ & $\mathbf{E}$ & $0(\%)$ & $\mathbf{E}$ & \\
\hline 1 & Up to 36000 & $\begin{array}{c}19 \\
(42.2)\end{array}$ & 7.83 & $36(18.7)$ & 33.57 & $5(4.7)$ & 18.61 & $60(17.4)$ \\
\hline 2 & $\begin{array}{l}36001- \\
48000\end{array}$ & $11(24.5)$ & 9.00 & $46(23.8)$ & 38.60 & $\begin{array}{c}12 \\
(11.2)\end{array}$ & 21.40 & $69(20.0)$ \\
\hline 3 & Above 48000 & $\begin{array}{c}15 \\
(33.3)\end{array}$ & 28.17 & $\begin{array}{c}111 \\
(57.5)\end{array}$ & 120.83 & $\begin{array}{c}90 \\
(84.1)\end{array}$ & 66.99 & $\begin{array}{c}216 \\
(62.6)\end{array}$ \\
\hline \multicolumn{2}{|c|}{ Aggregate (\%) } & \multicolumn{2}{|c|}{$45(13.1)$} & \multicolumn{2}{|c|}{$193(55.9)$} & \multicolumn{2}{|c|}{$107(31.0)$} & $\begin{array}{c}345 \\
(100)\end{array}$ \\
\hline
\end{tabular}

Source: Computed from Primary Data

The Table 9 indicates that family size of 1-2, 3-4 and above 4 were belonged the maximum annual household income below Rs. 36001(42.2 per cent), above Rs.48000 (57.5 per cent) and above Rs. 48000 (84.1 per cent) respectively. Three to four members (have) families were major participants in the Act (55.9 per cent).

\subsubsection{ASSOCIATION BETWEEN ANNUAL INCOME AND EMPLOYEES OF THEIR FAMILY}

The government and private sector employees are mostly retiring between the ages from 58 to 65. Agricultural or allied laboures/farmers and illiterate peoples they have no retirement in their entire life of rural society.

From the Table 10 , the number of employees of the respondent families was classified as 1-2 and above two, and they were belonged the maximum annual household income group of below Rs. 48001 (53.0 per cent) and above Rs.60000 (77.0 per cent) respectively. Above two employees have a family getting more income than other 


\begin{tabular}{|c|c|c|c|c|c|c|}
\hline \multirow[t]{3}{*}{ Sl. No } & \multirow{3}{*}{ Income In Rs. } & \multicolumn{4}{|c|}{ EMPLOYEES (In Count) } & \multirow[t]{3}{*}{ Total (\%) } \\
\hline & & \multicolumn{2}{|c|}{$1-2$} & \multicolumn{2}{|c|}{ Above 2} & \\
\hline & & O (\%) & $\mathbf{E}$ & $\mathrm{O}(\%)$ & $\mathbf{E}$ & \\
\hline 1 & Up to 48000 & $123(53.0)$ & 86.75 & $6(5.3)$ & 42.25 & $129(37.4)$ \\
\hline 2 & $48001-60000$ & 69 (29.7) & 59.85 & 20 (17.7) & 29.15 & 89 (25.8) \\
\hline 3 & Above 60000 & $40(17.3)$ & 85.40 & $87(77.0)$ & 41.60 & $127(36.8)$ \\
\hline \multicolumn{2}{|c|}{ Aggregate (\%) } & \multicolumn{2}{|c|}{$232(67.2)$} & \multicolumn{2}{|c|}{$113(32.8)$} & $345(100)$ \\
\hline
\end{tabular}

Source: Computed from Primary Data

classified employees' group. Therefore, annual household incomes were determined by the number of employees of the family. The majority of the participants were from only two employees of the families (67.2 per cent) in MGNREGA.

\subsubsection{ASSOCIATION BETWEEN ANNUAL INCOME AND MIGRANT WORKERS OF THEIR FAMILY}

More income expectations, modern life, more expensive, low employment situation, poverty, unavailability of basic facilities and natural disorder are the main reasons for human migration. Meanwhile, the study deals only with migrant workers of respondent family (family members' migration for job purpose only).

\begin{tabular}{|c|c|c|c|c|c|c|}
\hline \multirow[t]{3}{*}{ Sl. No } & \multirow[t]{3}{*}{ Income In Rs. } & \multicolumn{4}{|c|}{ MIGRANT WORKERS } & \multirow[t]{3}{*}{ Total (\%) } \\
\hline & & \multicolumn{2}{|c|}{ No } & \multicolumn{2}{|c|}{ Yes } & \\
\hline & & $0(\%)$ & $\mathbf{E}$ & 0 (\%) & $\mathbf{E}$ & \\
\hline 1 & Up to 24000 & $20(8.6)$ & 19.59 & $9(8.0)$ & 9.41 & $29(8.4)$ \\
\hline 2 & $24001-36000$ & $24(10.3)$ & 20.94 & $7(6.2)$ & 10.06 & $31(9.0)$ \\
\hline 3 & $36001-48000$ & $52(22.3)$ & 46.60 & $17(15.2)$ & 22.40 & $69(20.0)$ \\
\hline 4 & $48001-60000$ & $68(29.2)$ & 60.11 & 21 (18.8) & 28.89 & $89(25.8)$ \\
\hline 5 & Above 60000 & $69(29.6)$ & 85.77 & $58(51.8)$ & 41.23 & $127(36.8)$ \\
\hline \multicolumn{2}{|c|}{ Aggregate (\%) } & \multicolumn{2}{|c|}{$233(67.5)$} & \multicolumn{2}{|c|}{$112(32.5)$} & $345(100)$ \\
\hline
\end{tabular}

Source: Computed from Primary Data

The Table 11 shows that, migrant and non-migrant workers of the respondents' families were belonged in the annual household income group of above Rs. 60000 (51.8 per cent and non 29.6 per cent). It is illustrated that migrant workers families were more annual household income than non-migrant workers families. Nonmigrant families were major participants in MGNREGA (67.5 per cent). 


\subsection{CHI-SQUARE TEST RESULTS FOR INDENTIFY THE ASSOCIATION BETWEEN}

\section{Hypothesis}

$\mathbf{H}_{0}$ - There is no significant level of association between annual income of respondents and their socio-economic conditions

$\mathbf{H}_{1}$ - There is a significant level of association existing between annual income of respondents and their socio-economic conditions

Table 12 Chi-Square Test Results for indentify the Association between Income Distribution and Socio-Economic Conditions of MGNREGA Workers/Households

\begin{tabular}{|c|c|c|c|c|c|c|}
\hline $\begin{array}{l}\text { Sl. } \\
\text { No }\end{array}$ & Variable & $\begin{array}{c}\text { Calculated } \\
\text { Value }\end{array}$ & $\begin{array}{c}\text { Degrees of } \\
\text { freedom }\end{array}$ & $\begin{array}{l}\text { Table } \\
\text { Value }\end{array}$ & $\begin{array}{l}\text { p-value } \\
\text { (At 5\%) }\end{array}$ & $\begin{array}{l}\text { Hypothesis } \\
\text { Result }\left(\mathrm{H}_{0}\right)\end{array}$ \\
\hline 1 & Gender - R & 15.1303 & 3 & 7.815 & $.001709^{* *}$ & Rejected \\
\hline 2 & Age - R & 22.439 & 9 & 16.919 & $.007587^{* *}$ & Rejected \\
\hline 3 & Education - R & 2.389 & 3 & 7.815 & .49569 & Accepted \\
\hline 4 & $\begin{array}{c}\text { Marital Status } \\
-\mathrm{R}\end{array}$ & 1.7902 & 4 & 9.488 & .774281 & Accepted \\
\hline 5 & $\begin{array}{c}\text { Community - } \\
\text { R }\end{array}$ & 10.0575 & 3 & 7.815 & $.018084^{* *}$ & Rejected \\
\hline 6 & $\begin{array}{c}\text { Occupation - } \\
\text { R }\end{array}$ & 52.3283 & 6 & 12.592 & $0.00001^{* *}$ & Rejected \\
\hline 7 & $\begin{array}{c}\text { Type of House } \\
-(\mathrm{H})\end{array}$ & 8.2257 & 6 & 12.592 & .22203 & Accepted \\
\hline 8 & $\begin{array}{c}\text { Type of Family } \\
-(\mathrm{H})\end{array}$ & 16.1536 & 2 & 5.991 & $.000311^{* *}$ & Rejected \\
\hline 9 & $\begin{array}{c}\text { Size of Family } \\
-(\mathrm{H})\end{array}$ & 46.9377 & 4 & 9.488 & $0.00001^{* *}$ & Rejected \\
\hline 10 & $\begin{array}{c}\text { Employees - } \\
\text { (H) }\end{array}$ & 124.2202 & 2 & 5.991 & $0.00001^{* *}$ & Rejected \\
\hline 11 & $\begin{array}{c}\text { Migrant } \\
\text { Workers - }(\mathrm{H})\end{array}$ & 16.6295 & 4 & 9.488 & $.002281^{* *}$ & Rejected \\
\hline
\end{tabular}

Source: Computed from Primary Data **- Significant Notes: R- Annual Income of Respondent H- Annual Household Income of Respondent

\subsubsection{ASSOCIATION BETWEEN INCOME AND GENDER}

In the case of Table 12 , null hypothesis $\left(\mathrm{H}_{0}\right)$ is rejected and alternative hypothesis $\left(\mathrm{H}_{1}\right)$ is accepted because of $\mathrm{x}^{2}(15.1303)$ greater than the table $(7.815)$ value at 5 per cent level (p-.001709) of significance. As a result, there is some significant association between respondents' annual income and their gender. MGNREGA ensures equal wage to men and women, but agriculture and allied employments do not give equal wage to them. Gender wise income variation has been existed in the study area. 


\subsubsection{ASSOCIATION BETWEEN INCOME AND AGE}

As a result, from table-12, the calculated Chi-square $\left(x^{2}=22.439\right)$ value is greater than the table (16.919) value at 5 per cent level. The p-value is .007587. The result is significant at $\mathrm{p}<.05$. Therefore, $\mathrm{H}_{0}$ is rejected and the $\mathrm{H}_{1}$ is accepted. Hence this study found that there is some significant association between respondents' annual income and their age groups. Age has been important to determine the respondent's annual income. Middle age group (31-40) participants' have higher income than others.

\subsubsection{ASSOCIATION BETWEEN INCOME AND EDUCATIONAL STATUS}

The calculated (Table-12) Chi-square $\left(\mathrm{x}^{2}=2.389\right)$ value is less than the table (7.815) value at 5 per cent level. The $\mathrm{p}$-value is .49569 . The result is not significant at $\mathrm{p}<$ .05. Therefore, $\mathrm{H}_{0}$ is accepted and $\mathrm{H}_{1}$ is rejected. Hence this study found that there is no significant association between respondents' annual income and socio-economic factor of their education. Educational status does not influence income earning in the study area. Educated and uneducated respondents were getting same wage.

\subsubsection{ASSOCIATION BETWEEN INCOME AND MARITAL STATUS}

12 revealed that the calculated Chi-square $\left(x^{2}=1.7902\right)$ value is less than the table (9.488) value at 5 per cent level. The p-value is .774281 . The result is not significant at $\mathrm{p}<.05$. Therefore, null hypothesis $\left(\mathrm{H}_{0}\right)$ is accepted and alternative hypothesis $\left(\mathrm{H}_{1}\right)$ is rejected. Hence this study found that there is no significant association between respondents' annual income and their marital status. Respondents' annual income does not depend upon their marital status of the study area.

\subsubsection{ASSOCIATION BETWEEN INCOME AND COMMUNITY}

In table-12, the calculated Chi-square $\left(x^{2}=10.0575\right)$ value is greater than the table (7.815) value at 5 per cent level. The p-value is .018084 . The result is significant at $\mathrm{p}<.05$. Therefore, null hypothesis $\left(\mathrm{H}_{0}\right)$ is rejected and the alternative hypothesis $\left(\mathrm{H}_{1}\right)$ is accepted. Hence this study finds that there is some significant association between respondents' Annual Income and their community. The interrelationship exists between annual income of respondents' and their community. SCG is economically wealthy society than SCA. SCA gets an annual income of above Rs. 48000, its only 29 percent compares to SCG. SCG has Rs. 36000-48000, but it's 35 per cent.

\subsubsection{ASSOCIATION BETWEEN INCOME AND OCCUPATIONS}

The table-12 revealed that the calculated Chi-square $\left(x^{2}=52.3283\right)$ value is greater than the table (12.592) value at 5 per cent level. The $p$-value is $<0.00001$. The result is significant at $\mathrm{p}<.05$. Therefore, null hypothesis $\left(\mathrm{H}_{0}\right)$ is rejected and the alternative hypothesis $\left(\mathrm{H}_{1}\right)$ is accepted. Hence this study found that there is some signifi- 
cant association between respondents' annual income and their occupation. Respondents' annual income has determined by respondents' occupations of the study area.

\subsubsection{ASSOCIATION BETWEEN ANNUAL INCOME AND TYPE OF HOUSES}

12 shows that, the calculated Chi-square $\left(x^{2}=8.2257\right)$ value is less than the table (12.592 value at 5 per cent level. The p-value is .22203. The result is not significant at $\mathrm{p}<.05$. Therefore, null hypothesis is accepted and the alternative hypothesis is rejected. Hence this study found that there is no significant level of association between annual household income and type of house. Therefore, there is no relationship between them.

\subsubsection{ASSOCIATION BETWEEN ANNUAL INCOME AND TYPES OF FAMILY}

The table-12 indicates that the calculated Chi-square $\left(x^{2}=16.1536\right)$ value is greater than the table (5.991) value at 5 per cent level. The p-value is .000311 . The result is significant at $\mathrm{p}<.05$. Therefore, null hypothesis is rejected and the alternative hypothesis is accepted. Hence this study found that there is a significant level of association existing between annual household income and their families. Joint family was getting higher annual income than nuclear family. Therefore, annual household income was depending upon type of family system.

\subsubsection{ASSOCIATION BETWEEN ANNUAL INCOME AND SIZE OF FAMILY}

In table-12, the calculated Chi-square $\left(x^{2}=46.9377\right)$ value is greater than the table (9.488) value at 5 per cent level. The p-value is $<0.00001$. The result is significant at $\mathrm{p}<.05$. Therefore, null hypothesis is rejected and the alternative hypothesis is accepted. Hence this study found that there is a significant level of association existing between annual households' income and their size of family. Therefore, annual household income was determined by the size of family.

\subsubsection{ASSOCIATION BETWEEN ANNUAL INCOME AND EMPLOYEES OF THEIR FAMILY}

The table-12 shows that the calculated Chi-square $\left(x^{2}=124.2202\right)$ value is greater than the table (5.991) value at 5 per cent level. The $p$-value is $<0.00001$. The result is significant at $\mathrm{p}<.05$. Therefore, null hypothesis is rejected and the alternative hypothesis is accepted. Hence this study found that there is a significant level of association existing between annual household income and number of employees in their families. Therefore, more incomes were from more employees of the family. 


\subsubsection{ASSOCIATION BETWEEN ANNUAL INCOME AND MIGRANT WORKERS OF THEIR FAMILY}

In table-12, the calculated Chi-square $\left(x^{2}=16.6295\right)$ value is greater than the table (9.488) value at 5 per cent level. The p-value is .002281. The result is significant at $\mathrm{p}<.05$. Therefore, null hypothesis is rejected and the alternative hypothesis is accepted. Hence this study found that there is any significant association between annual household income and their family member's migration. The past study Kareemulla et al. (2013) depicted that the income from migration also has decreased during MGNREGS period compared to the pre-MGNREGS period. Therefore, MGNREGA decreased the migration in rural India; while the present study illustrated those migrant workers, families were more annual household income than non-migrant workers families.

\section{CONCLUSION}

This study found that females, daily wage earners, married, youngest, illiterate, SCG category, thatched/tiled houses, nuclear families and non-migrant workers were the major participants in MGNREGA programe. Joint family was getting higher annual income than nuclear family. Size of family determines increase or decrease of the annual household income. As a result, more incomes were from more employees of the family.

The study concluded that there is a significant level association existing between annual income of MGNREGA workers/households and their socio-economic conditions, such as the participants' gender, age, community and occupation, type of family, size of family, number of employees and migrant workers of the family in the study area. While, there is no significant level association existing between annual income and socio-economic conditions with respect to education, type of houses, and marital status. Hence, the MGNREGA is one of the major factors in determining the income level and also the socio-economic conditions of the of scheduled castes workers in the study area.

\section{SUGGESTIONS}

If one analyses the economic history of poverty reduction in India right from First Five Year Plan to end of the Twelfth Five Year Plan one could understand that the answer for this doubt seems to be in that direction only. The Director Sathyajith Ray one who took movie about poverty in India, was rewarded with best Directors Award, the Economist Amartiya Sen one who wrote intensively about poverty was rewarded with Nobel Prize, Muhammd Yunus one who introduced the concept of Micro-finance/Self Help Groups among poor Women in Bangladesh was rewarded with Nobel Prize, Mother Teresa one who dedicated her life for the poor was rewarded with Nobel Prize, the film "Salaam Bombay" rewarded with a 
lot of awards in India and abroad and the list continues till now. All those who wrote intensively about poverty in India, those who took movies about poverty in India, those who acted in movies as poor person, it seems that, became very rich in India and also in abroad. But the people who are living below the poverty line still living under poverty only. Only the definitions changed from the amount of calories needed in a day to wage per day, then it ended with multi-dimensional approach to poverty. The government or the government appointed committees like Y K Alagh Committee, Lakdawala Formula, Suresh Tendulkar Committee, C. Rangarajan Committee though varies from one another with respect to number of people who live below the poverty line in India, have one common point that is the per centage of poverty reduction is not as expected level, whatever may be their approaches in defining poverty. The socio-economic Census 2011 has stated out of 1000 million people, who live in rural India, fifty per cent of them have less than five cents of land. They are simply daily wage workers, agri cooli workers or casual labourers in farm sector. Unless these people get an opportunity, either directly or indirectly, of what is going on in the State Assemblies of different states and Parliament of India, no policies, programmes and schemes will help them to improve their standard of live. So governments both central and states should go for digitalisation of the rural areas immediately. Employment generation schemes, income generation schemes, poverty eradication programmes in rural areas should be very well connected and operated only through their bank accounts. Digitalisation is the only way to get rid of corruption at all levels. Definitely the targeted group will get benefit out of digitalisation. (1). Huge investment on infrastructural facilities like Bullet train, eight-line highways, port development, more airports, constructing large dams etc. (2). More liberalisation of FDI with respect to retail sector, export and import tariff etc. (3). More investment to boost the agricultural sector and rural infrastructural development. Starting food processing industries with air-conditioned warehousing facilities and air-conditioned containers facilities in village level at least block level in the beginning are welcome one. Repair and maintenance of existing ponds, lakes and canals for water harvesting and constructing more check dams to store the water should be considered at war footing. (4). More allotment to MSME under start-up programme, make in India programme and Mudra scheme. (5). Atleast consolidation of Fiscal deficit at current level is a well come effort. If the above items are considered seriously and incorporated in the budgets in the coming years, we hope that it will solve the basic and fundamental burning problems like unemployment, poverty, rural development and social inequality within five years Arunachalam (2021).

\section{REFERENCES}

Adi Dravidar And Tribal Welfare Department Of Tamil Nadu. (2009). G.O. No. 55. Dated On 8.4.2009.

Arunachalam, P. (2021). Impact Of Great Depression And Covid -19. Serials Publications (P) 
Lted.,4830/24, Ansari Road, Darya Ganj, 978, 8194793267-8194793267.

Devi, T. S., R, B. B., \& Kumar, G. (2011). Employment, Income And Labour Supply Decision Of Rural Households: An Economic Analysis Of MGNREGS In Tamil Nadu". Agricultural Economics Research Review, 24, 473-484.

Jha, S. (2014). Fewer Poor Among SC, ST, OBC, Business Standard, March.

Kareemulla, K., Ramasundaram, P., Kumar, S., \& Rao, C. R. (2013). Impact of National Rural Employment Guarantee Scheme in India on Rural Poverty and Food Security. Current Agriculture Research Journal, 1(1), 13-28. Retrieved from https://dx.doi.org/10 .12944/carj.1.1.02 10.12944/carj.1.1.02

Kothari, C. R. (2004). Research Methodology". 2nd Ed., New Age International Publishers, 232232.

Mary, R., \& M. (2014, March). A Study On Rural Development Through Employment Generation Programs In Madurai District- A Case Study. (pp. 111-116). Madurai: Shanlax Publications.

Ministry Of Law And Justice Of India . (2005). The National Rural Employment Guarantee Act 7th September.

Mishra, P., Behera, B., \& Nayak, N. C. (2010). A Development Delivery Institution for the Tribal Communities: Experience of the National Rural Employment Guarantee Scheme in India. Development Policy Review, 28(4), 457-479. Retrieved from https://dx.doi.org/ 10.1111/j.1467-7679.2010.00492.x 10.1111/j.1467-7679.2010.00492.x

Mukherjee, S. (2016). Business-Standard, New Delhi. P.4, 2nd February. Neil, U., \& R. (1978). Elementary Statistics-An Applied Approach., 234-234.

Veena, K. (2015). Impact Of MGNREGA On Agricultural Wage Rates". International Journal of Multidisciplinary Advanced Research Trends, 2(1), 1-7. 